University of California, Hastings College of the Law UC Hastings Scholarship Repository

Faculty Scholarship

1993

\title{
Guideline Developments in the First Circuit: The Two Faces of Appellate Review
}

Aaron J. Rappaport

UC Hastings College of the Law, rappapor@uchastings.edu

Follow this and additional works at: http://repository.uchastings.edu/faculty_scholarship

Part of the Criminal Law Commons, and the Criminal Procedure Commons

\section{Recommended Citation}

Aaron J. Rappaport, Guideline Developments in the First Circuit: The Two Faces of Appellate Review, 5 Fed. Sent. R. 267 (1993). Available at: http://repository.uchastings.edu/faculty_scholarship/668

This Article is brought to you for free and open access by UC Hastings Scholarship Repository. It has been accepted for inclusion in Faculty Scholarship by an authorized administrator of UC Hastings Scholarship Repository. For more information, please contact marcusc@uchastings.edu. 


\title{
Faculty Publications \\ UC Hastings College of the Law Library
}

\author{
Author: Aaron J. Rappaport \\ Source: Federal Sentencing Reporter \\ Citation: 5 Fed. Sent. R. 267 (1993). \\ Title: Guideline Developments in the First Circuit: The Two Faces of Appellate Review
}

Originally published in FEDERAL SENTENCING REPORTER. This article is reprinted with permission from FEDERAL SENTENCING REPORTER and University of California Press; Vera Institute of Justice. 


\section{APPELLATE REVIEW}

\section{GUIDELINE DEVELOPMENTS IN THE FIRST CIRCUIT:} THE TWO FACES OF APPELLATE REVIEW

\author{
Aaron Rappaport *
}

How closely should the appellate courts scrutinize district court sentencing decisions? According to the First Circuit, the answer is: It depends. The court has adopted a "good cop/bad cop" approach to appellate review.

For decisions within the guidelines - such as enhancement and adjustment decisions - the Circuit has applied a lenient review standard, giving the trial courts virtually free reign to choose an appropriate guideline range. However, where the district court has departed from the designated guideline range based on factors "not adequately considered" by the Commission, the Circuit's review has been sharp and intrusive. As a result, the message to the district courts has been a simple one: Do whatever you want, just don't depart.

This comment examines the dual approach to appellate review found in the First Circuit. It concludes that the court's divergent standards for reviewing departure decisions and guideline applications rest on conflicting assumptions about the legal, institutional, and policy factors underlying the sentencing guidelines. As a result, the two approaches remain in subtle tension, a tension that may portend future changes in what now appears to be settled circuit doctrine.

\section{REVIEW OF GUIDELINE ADJUSTMENTS AND ENHANCEMENTS}

The First Circuit's review of guideline adjustments and enhancements has been relatively deferential. An early guideline case, United States $v$. Wright, ${ }^{1}$ has formed the cornerstone for that approach. In Wright, Judge Breyer fashioned the standard for reviewing a district court's role-in-the-offense decisions. Judge Breyer acknowledged that these decisions raise the kind of questions - involving application of a legal standard to undisputed facts-that "are usually called 'mixed questions' of fact and law." 2 He ruled that, while mixed questions are often reviewed de novo like pure questions of law, the clearly erroneous standard is more appropriate in the sentencing context.

This holding was required, Judge Breyer indicated, as a matter of law, institutional competence, and sentencing policy. First, the Sentencing

* Counsel, U.S. Senate Committee on the Judiciary, Subcommittee on the Constitution. My thanks to Francesca Bowman for her encouragement and advice.
Reform Act as amended explicitly authorized appellate courts to give "due deference" to the district court's application of the guidelines to the facts. The due deference standard "foresees that strict appellate review of Guidelines application questions may not be appropriate." ${ }^{\prime 3}$

Second, Judge Breyer observed that role in the offense decisions fell within the district court's broad area of competence, since these decisions were heavily dependent "on the application of the factfinding tribunal's experience with the mainsprings of human conduct." 4 Moreover, the district court's resolution of these questions "raises no important, widely applicable issues of law." ${ }^{5}$

Finally, as a matter of sentencing policy, Judge Breyer found that a strict review

might hinder the Commission's legal power and expressed intention to collect information about how the district courts apply the Guidelines and to revise them in light of what it learns. . . . Too intrusive a standard of appellate review could impede the Commission's efforts to learn from district courts' experience. ${ }^{6}$

Following the Wright decision, the First Circuit applied its deferential standard of review to numerous other "mixed questions of law and fact," in some cases explicitly positioning the court at odds with other, less yielding, circuits. The court, for example, extended the clear error standard to a district court's grouping of counts, ${ }^{7}$ to certain relevant conduct determinations, ${ }^{8}$ to numerous kinds of offense enhancements, ${ }^{9}$ to the use of acquitted conduct for enhancement purposes, ${ }^{10}$ and to the district court's choice of "the most analogous guideline" when no directly applicable guideline exists. ${ }^{11}$

The result has been the establishment in the First Circuit of a broad area of relative freedom for district courts in their identification of appropriate guideline ranges. ${ }^{12}$

\section{REVIEW OF DEPARTURE DECISIONS}

In contrast to the Wright-based body of law, the First Circuit has taken an active role in policing district courts' decisions to depart from the relevant guideline range. The leading case is Diaz-Villafane, ${ }^{13}$ in which Judge Selya first set out the circuit's threepart test for evaluating departures. The Court has summarized the Diaz-Villafane test as follows:

First, we consider whether circumstances relied on by the sentencing court warranted a departure ... Second, we determine whether circumstances relied on by the sentencing court are present in the appellant's case; findings of fact are reviewed for clear error. Third, we evaluate the reasonableness of the direction and degree of the challenged departure. The reasonableness determination is "quintessentially a judgment call," primarily entrusted to the district court. ${ }^{14}$ 
A number of circuits have explicitly adopted the DiazVillafane test: ${ }^{15}$ others have adopted similar standards of review. ${ }^{16}$

The critical part of the Diaz-Villafane test is the first prong, since this has represented the most common stumbling block for district court departures. At this step, the appellate court must determine if the circumstances in the case are "sufficiently 'unusual' to warrant departure." Judge Selya has stated that the court's review here "is plenary: whether or not circumstances are of a kind or degree that they may appropriately be relied on to justify departure is, we think, a question of law."17

A plenary, or de novo, standard of review has enabled the First Circuit to substitute its own judgment about the validity of departure rationales for that of the district court. In doing so, the First Circuit has exhibited a relatively narrow view of permissible departure factors, especially in the case of downward departures. Since 1987, the circuit has reversed at least nine downward departures; none has been affirmed. ${ }^{18}$

Arguably, a few of these decisions would have been decided differently under a more deferential standard of review. A striking example is United States $v$. Sklar, ${ }^{19}$ which one defense attorney called "the worst case yet under the guidelines." In Sklar, the trial court imposed a 30 month sentence on the defendant for drug trafficking, departing downward from a minimum guideline sentence of 37 months. The court cited, among other things, the

fact that the defendant attempted to rehabilitate himself in the past year, went to several halfway houses and rehabilitation centers to make a new life for himself away from drug addiction and is continuing to go about that course of action.

The First Circuit reversed. While it acknowledged that pre-sentence rehabilitation may justify a departure in an unusual case, the court rejected "the sentencing judge's determination that this case constitutes such an exception." ${ }^{20}$ The court observed that,

some degree of presentence rehabilitation is usually to be expected from a penitent defendant ... or even from one who simply wants to put his best foot forward at sentencing, hopeful of lightening the load.21

In contrast, the Second Circuit has recently affirmed a relatively large departure based on the defendant's pre-sentence rehabilitation, reviewing the district court's decision under the more lenient standard of "reasonableness." In United States $v$. Maier, ${ }^{22}$ the court imposed a 4 year probationary sentence on a drug offender, rather than a prison sentence in the 55-63 month guideline range. The Circuit observed that the trial court

has not departed simply because the defendant has entered a rehabilitation program. Such programs, easily entered but difficult to sustain, cannot be permitted to become an automatic ground for obtaining a downward departure. Instead, the District Judge has conscientiously examined all the pertinent circumstances. ... [We] conclude that the departure is not "unreasonable," which is the ultimate standard of guiding our review of departures. 23

According to Francesca Bowman, deputy chief probation officer in Massachusetts, the First Circuit's strict departure review has been a significant factor in the district courts' reluctance to initiate departures, at least absent a prosecutor's motion for substantial assistance. For example, she observes that the percentage of cases falling outside the designated guideline range has remained more or less constant between 1989 and 1991. However, the composition of these departures has changed markedly. As the proportion of substantial assistance departures increased from 13 to $19 \%$ of all cases between 1989 and 1991, the number of other downward departures fell from 21 to $8 \%$ of all cases. $^{24}$

\section{DEPARTURES FROM THE GUIDELINES ${ }^{25}$ (D. Mass)}

TYPES OF DEPARTURES
Total Subst. Other
Departures Assist. Downward Upward

$\begin{array}{llllll}\text { 1989: } & 168 & 61(37 \%) & 23(13 \%) & 36(21 \%) & 2(1 \%) \\ \text { 1990: } & 270 & 75(28 \%) & 41(15 \%) & 25(9 \%) & 9(3 \%) \\ \text { 1991: } & 335 & 96(29 \%) & 65(19 \%) & 27(8 \%) & 4(1 \%)\end{array}$

\section{QUESTIONING DIAZ-VILLAFANE}

While the Diaz-Villafane test has been applied to numerous cases in the First Circuit, the court has yet to offer a detailed defense of its theory of departure review. This reticence stands in marked contrast to the thoughtful analysis in Wright of the factors legal, institutional, and policy-related - that warrant a clear error review of "role in the offense" adjustments. These same three factors, applied to the departure decision, raise significant questions about the soundness of the Diaz-Villafane standard.

First, as in the Wright-based body of law, Congress enacted a specific standard of appellate review for departure cases, authorizing the courts to reverse departures deemed "unreasonable." ${ }^{26}$ Like the "due deference" standard governing guideline applications in Wright, "reasonableness" suggests a range of permissible departure justifications. While reasonableness does not necessarily call for the same clear error review adopted in Wright, it does seem to require at least some deference to the district court's stated rationale for its departure decision. 
Second, the first prong of the Diaz-Villafane test treats, as a pure question of law, one of the central questions in the departure decision: Does a factor exist that serves to remove the case from the "heartland" of cases? Undoubtedly, cases may exist where the departure decision represents a pure question of law-such as situations where the district court fails to observe a relevant guideline provision or misconstrues its authority to depart. In those cases, a standard approaching de novo review may be appropriate.

But the typical departure decision is more factbound, requiring a court both to (a) identify any significant facts present in the specific case, and (b) compare these facts to the "heartland" of criminal cases. Like the Wright-line of cases, this kind of analysis is appropriately deemed a mixed question of law and fact. ${ }^{27}$ As in Wright, the departure decision depends, in part, on "the application of the factfinding tribunal's experience with the mainsprings of human conduct." And, since it depends on difficultto-define judgments about the contours of the "heartland" and its relationship to the specific facts before the court, the district court's departure decision often "raises no important, widely applicable issues of law." These institutional factors, while perhaps not significant enough to warrant clear error review, call for a standard more deferential than de novo review.

Finally, the policy considerations that drove the Wright decision-a sensitivity to the evolutionary nature of the guideline system - would seem to apply with particular force to the departure decision as well. Indeed, in Diaz-Villafane, Judge Selya himself acknowledged the need to preserve some margin of discretion for the district court in making departure decisions. Toward the end of the opinion, he states:

We envision[] considerable discretion in departure decisions, at least at this early stage of their existence. Although we are cognizant that departures should be the exception rather than the rule, we must nonetheless defer, within broad limits, to the trial judge's intimate familiarity with the nuances of a given case. ${ }^{28}$

\section{LOOKING AHEAD}

The legal and policy factors underlying the Wright decision and its progeny throw into sharp relief the structural weakness of Diaz-Villafane. An alternative standard would review departures for "reasonableness," and implement the kind of deference for district court decisions called for by considerations of law, institutional competence and sentencing policy. Will the First Circuit move in this direction? Will it abandon its good cop/bad cop approach to appellate review?

Perhaps. In a few recent upward departure cases, the First Circuit appears to have adopted a relatively deferential posture, one that may suggest discomfort with the strict de novo review standard. In U.S. v. Tilley, for example, the district court departed upward based on a determination that the defendant's criminal history score did not adequately reflect the seriousness of his offense. The First Circuit affirmed, making only passing reference to Diaz-Villafane. It concluded that, "we will not curtail the district court's discretion to impose sentence unless it is clearly beyond the realm of reasonableness. The district court's action in this case was not." ${ }^{29}$

A clean break with Diaz-Villafane, however, is unlikely. A moderate and collegial court, the First Circuit is unlikely to convene an en banc panel to reverse settled court doctrine, especially given the depth of precedent following the Diaz-Villafane decision.

Nonetheless, subtle changes might help to move the court in the right direction. One possible step would be to limit the scope of the critical first prong of the Diaz-Villafane test. The court, for example, might restrict this prong's de novo review standard to issues that truly represent pure questions of law. Under this approach, departures based on mixed questions of law and fact would pass through the stringent first prong of the Diaz-Villifane test without obstruction; the third prong's test of "reasonableness" would then govern.

This proposal, of course, would not abolish the Diaz-Villafane test. But it would recast its character. By narrowing the scope of the first prong and expanding the third, the proposal would help bridge the troubling gap between the Wright and DiazVillafane bodies of law.

\section{FOOTNOTES}

1873 F.2d 437, 443 (1st Cir. 1989)

${ }^{2}$ Id. at 443 .

${ }^{3} \mathrm{Id}$. at 443.

${ }^{4}$ Id. at 444 (citing United States v. McConney, 728 F.2d 1195, 1202 (9th Cir. 1984)).

${ }^{5} \mathrm{Id}$. at 444.

${ }^{6}$ Id. at 444 (citing Pierce $v$. Underwood, 487 U.S. 552 (1988) (deferential appellate review appropriate where a statute's proper application is a "novel question ... likely to profit from the experience that an abuse of discretion rule will permit to develop."))

7 United States v. Pilgrim Market, 944 F.2d 14, 17 (1st Cir. 1991) (circuit applies clear error review of mixed questions of law and fact relating to grouping of counts, even though other circuits may apply de novo review).

${ }^{8}$ United States v. Garcia, 954 F.2d 12, 16 (1st Cir. 1992) (sentencing court's determination that drug transactions did, or did not, form part of the same course of conduct as the counts of conviction is a predominantly factual finding that will be disturbed only if clearly erroneous); United States $v$. Tabares, 951 F.2d 405, 409 (1st Cir. 1991) (similar).

9 United States v. Newman, 982 F.2d 665 (1st Cir. 1992) (sentencing enhancement for "serious bodily injury" under U.S.S.G. \$2A2.2 reviewed for clear error); United States $v$. Jimenez-Otero, 898 F.2d 813, 814-15 (1st Cir. 1990) (district 
court's findings regarding defendant's purpose in holding screwdriver during crime reviewed for clear error); United States v. Preakos, 907 F.2d 7, 8 (1st 1990) (adjustment under U.S.S.G. §\$2D1.1(b)(1) and 3B1.1(a)); United States v. Paulino, 887 F.2d 358 (1st Cir. 1989) (sentence enhancement under \$2D1.1(b)(1))

10 See United States v. Pineda, 1992 U.S. App. LEXIS $32213,{ }^{*} 11$ (1st Cir. 1992) (no clear error for district court to conclude that gun was connected to drug offense, even though jury found otherwise at trial).

${ }_{11}$ United States v. Mariano, 1993 U.S. App. LEXIS 1552 (1st Cir. 1993) (interpreting \$2X5.1).

${ }_{12}$ See Francesca Bowman, The Greening of Probation Officers in Their New Role, 4 Fed. Sent. R. 99 (1991) ("It seems that the appellate courts for some time have been giving us ample direction. They have made it perfectly clear that there is latitude within the guidelines ... to make applications in aggravation or mitigation of the outcome.").

${ }^{13} 874$ F.2d 43, 49 (1st Cir. 1989).

${ }_{14}$ United States v. Polanco-Reynoso, 924 F.2d 23, 24 (1st Cir. 1991) (summarizing holding in Diaz-Villafane).

${ }_{15}$ See, e.g., United States $v$. Jones, 948 F.2d 732, 736 (D.C. Cir. 1991); United States v. Holmes, 975 F.2d 275, 283 (6th Cir. 1992); United States v. Joan, 883 F.2d 491, 494 (6th Cir. 1989); United States v. Lara-Banda, 972 F.2d 958, 959-60 (8th Cir. 1992); United States v. Williams, 922 F.2d 578, 581 (10th Cir. 1990).

${ }^{16}$ See, e.g., United States v. Lira-Barraza, 941 F.2d 745, 746 (9th Cir. 1991) (three-step test: "The first is to determine whether the district court had legal authority to depart... Second, we review for clear error factual findings supporting the existence of the identified circumstance. ...Third, we must determine whether the extent of departure from the applicable Guideline range was "unreasonable" ...."). See also Bruce M. Selya and Matthew R. Kipp, An Examination of Emerging Departure Jurisprudence Under the Federal Sentencing Guidelines, 67 Notre Dame L. Rev. 1 (1991).

${ }^{17} 874$ F.2d at 49 (emphasis added).

${ }_{18}$ See United States $v$. Williams, 891 F.2d 962 (1st Cir. 1989) (departure based on defendant's cocaine dependency, lack of weapon, ineffectiveness as a criminal, desire to reform); United States v. Pozzy, 902 F.2d 133 (1st Cir. 1990) (departure based on defendant's pregnancy, husband's criminal influence, and lack of available halfway house); United States v. Studley, 907 F.2d 254 (1st Cir. 1990) (departure in child pornography case because defendant was a "useful citizen," kept his deviance to himself, was in a posture of rehabilitation, and because prison lacked counselling program); United States v. Deane, 914 F.2d 11 (1st Cir. 1990) (departure based on defendant's passive conduct in child pornography case, the lack of prison counselling program, and the defendant's "otherwise exemplary life"); United States $v$. Sklar, 920 F.2d 107 (1st Cir. 1990) (pre-sentence rehabilitation); United States $v$. Norflett, 922 F.2d 50 (1st Cir. 1990) (departure because defendant committed bank robberies "with no real violence" and with little monetary gain); United States $v$.Valencia-Lucena, 925 F.2d 506 (1st Cir. 1991) (departure based on government misconduct and on district court's uncertainty about the amount of cocaine found); United States v. Carr, 932 F.2d 67 (1st Cir. 1991) (departure based on defendants' responsibility for four year old child); United States $v$. Wogan, 938 F.2d 1446 (1st Cir. 1991) (departure to equalize sentences between codefendants). See also United States v. Delloiacono, 900 F.2d 481 (1st Cir. 1990) (even if the sentence is treated as a departure, the district court erred in combining probationary sentence with community service, rather than community confinement as required by U.S.S.G. \$5C2.1(c)). Cf. Francesca Bowman, The Greening of Probation Officers in Their New Role, 4 Fed. Sent. R. 99 (1991) (noting that a misleading impression of the district courts' ability to depart may be acquired if one looks exclusively at circuit cases, because the vast majority of downward departure cases are not appealed by the government).

But cf. United States v. Gregorio, 956 F.2d 341 (1st Cir. 1992) (rejecting defendant's challenge to the sentencing court's method of calculating extent of downward departure, but expressing approval of departure itself); United States v. Russell, 870 F.2d 18 (1st Cir. 1989) (court remands sentence because district court may have believed, erroneously, that it lacked the authority to depart downward based on defendant's "aberrant behavior.").

${ }_{19} 920$ F.2d 107 (1st Cir. 1990).

${ }^{20}$ Id. at 117.

${ }^{21} I d$ at 116 . While Sklar has discouraged departures based on pre-sentence rehabilitation, it has not eliminated all such cases. United States $v$. Leger is one example. The defendant in that case had been convicted of sexually exploiting children, 18 U.S.C. $\$ 2252(a)$, a crime that called for a guideline range of 12 to 18 months in prison. At sentencing, Judge Wolf conducted an evidentiary hearing, which revealed that Leger had joined a church after his arrest; the church's minister testified that Leger had renounced his unlawful ways. Citing this testimony, Judge Wolf departed downward, imposing a five year probationary sentence rather than an incarcerative term. Although he acknowledged the relevance of the Sklar decision, Judge Wolf stated,

The defendant has over 18 months exhibited extraordinary rehabilitation in the form of a religious conversion not contemplated by the Commission.... There was evidence in part by the testimony of the Pastor, who is on the board of Morality in Media.

The government did not appeal. One circuit obeserver later commented that Leger "goes to show that the courts have learned that, if you say the right words, you can still get away without getting appealed."

22975 F.2d 944 (2d Cir. 1992).

${ }^{23} \mathrm{Id}$. at 948 (emphasis added).

${ }^{24} \mathrm{~A}$ similar trend is evident throughout the Circuit. Between Fiscal Years 1990 and 1992, for example, the percentage of First Circuit cases that resulted in departures remained more or less constant (at around $20 \%$ of all sentences). However, during this period, substantial assistance departures increased from $6 \%$ to $12.8 \%$ of all sentences, while other downward departures fell from $7.4 \%$ to $5.5 \%$.

At the same time, it should be noted that the departure rates for individual districts within the Circuit have varied widely, ranging in 1992 from under 10\% in Maine and Rhode Island, to roughly 35\% in Massachusetts. 1992 United States Sentencing Comm'n Ann. Rep.

${ }^{25}$ Francesca Bowman, Commission, Congress Taking Disparate Paths, Mass. L. Wkly. 11 (May 18, 1992) (departure figures for 1991 have been updated using numbers supplied by Francesca Bowman). See also, Daniel J. Freed and Marc Miller, Departures Visible and Invisible: Perpetuating Variation in Federal Sentences, 5 Fed. Sent. R. 3 (1992) (discussing variations among the circuits in departure rates).

${ }_{26} 18$ U.S.C. $\$ 3742(\mathrm{e})(3)$ and $(\mathrm{f}(2)$. This view is supported by legislative history, see S. Rep. No. 225, 98th Cong., 2d Sess. 80 (1983), reprinted in 1984 U.S.C.C.A.N. 3182, 3263 ("If the appellate court finds that a sentence outside the guidelines is unreasonable, the case may be remanded to the trial court for resentencing ....), by the Guideline manual, see \$1A.2 ("If the court departs from the guideline range, an appellate court may review the reasonableness of the departure."), and by principal architects of the Guideline system, see William W. Wilkins, Jr., Sentencing Reform and Appellate Review, 46 Wash. \& Lee L. Rev. 429, 441-42 (1989) ("the language of subsections $3742(\mathrm{e})(3)$ and $(\mathrm{f})(2) \ldots$ requires an (continued on page 297) 